\title{
THE USE OF ACTIVE STRATEGIES FOR TEACHING LATIN SYNTAX: a case study of a Brazilian classroom experience ${ }^{1}$
}

Fábio Fortes*

(Universidade Federal de Juiz de Fora)

\begin{abstract}
In this paper, by showing a case study of a Latin teaching experience in Brazil, we discuss the relevance and usefulness of incorporating active strategies into the teaching of Latin syntax in a Brazilian university context. We mean here by active strategies any language practise consisting of producing language output, either orally or through writing, as a means of creating texts in this language to respond to classroom tasks. Our point is that through the development of task-based lessons with active strategies we may more easily engage students in their learning process and make more effective the learning of Latin syntax. We present a brief introductory discussion on what we consider to be how Latin is currently taught in Brazil, then we present an active teaching approach experience, and then we provide with some more conceptual arguments to justify such approach to this classical language.
\end{abstract}

KEYWORDS: Latin syntax, teaching, active strategies, engagement, orality

\section{O USO DE ESTRATÉGIAS ATIVAS PARA O ENSINO DA SINTAXE LATINA: ESTUDO DE CASO DE UMA EXPERIÊNCIA EM UMA SALA DE AULA NO BRASIL}

RESUMo: Neste artigo, discutimos a relevância e a utilidade de incorporar estratégias ativas ao ensino da sintaxe de latim, através de um estudo de caso de uma experiência de ensino no Brasil, em contexto universitário. Estamos considerando "estratégias ativas" toda prática de linguagem que consista na produção linguística, seja oralmente, seja por escrito, como resposta a tarefas dadas em sala de aula. Nosso argumento é que, através do desenvolvimento de aulas baseadas em tarefas, a partir do uso de estratégias ativas, podemos envolver mais facilmente os alunos no processo de aprendizagem e tornar mais eficaz o aprendizado da sintaxe latina. Apresentamos uma breve discussão introdutória sobre como o latim é atualmente ensinado no Brasil, depois apresentamos uma experiência ativa de abordagem de ensino para, em seguida, fornecemos alguns argumentos conceituais para justificar tal abordagem ainda que ela seja atualmente pouco usual para o ensino dessa língua clássica.

Palavras-Chave: Sintaxe do latim, ensino, estratégias ativas, engajamento, oralidade

\footnotetext{
1 This paper benefited from a scholarship for International Academic Mobility granted by the International Relations Office of the Universidade Federal de Juiz de Fora (UFJF), which allowed me to be a visiting professor at Philadelphia during the fall of 2019. It is also part of the Reseach Project "Práticas ativas no ensino de Latim: atividades em sala de aula. I am very thankful to Dr. Clifford Roulder, from the Center for the Advancement of Teaching at Temple University, whose assistance and teaching advise during my stay in Philadelphia were crucial for much of the ideas developed in this article.

*e-mail:
} 
Nowadays, it is common sense that memorising information is not enough for any learning process, language learning included. In fact, learning a language means being able to convey meaning in its contexts of use. Grammar acquisition is certainly part of it, but not the most important or exclusive element. However, when it comes to the teaching of Latin, the problem is how to help students actually learn the grammar, so that it does not become a mechanical, repetitive and eventually useless practice disconnected to the real use of the language. Besides that, an additional challenge is to help students go beyond morphology and undertand the Latin syntax, which is a crucial ability for reading. In order to address this issue, we discuss in this article the relevance and usefulness of incorporating active strategies into the teaching of Latin syntax. We mean here by active strategies any language practise consisting of producing language output, either orally or through writing, as a means of creating texts in this language to respond to classroom tasks.

Since Latin is not a contemporary living language, we would call such linguistic production extempore Latin, a term that highlights the considerable level of artificiality of such production in comparison to authentic historical Latin. Our point is that through the development of task-based lessons with active strategies we may more easily engage students in their learning process and help the acquisition of grammar, by exploring not only knowledge goals, but application and integration goals as well. We organise the paper as follows: we present a brief introductory discussion on what we consider to be how Latin is currently taught, then we present an active teaching approach experience carried out in a classroom in Brazil and then we provide some more conceptual arguments to justify such approach.

\section{$1 \quad$ What does it mean to learn Latin?}

To begin with, we would say that the acquisition of knowledge in school - no matter if it happens to be linguistic, scientific, technical or practical - actually implies grasping some piece of information that students may be presented with in a lecture or in an activity carried out in class. In fact, if we agree with the revised version of Bloom's Taxonomy of Educational Objectives (ANDERSON et al. 2001), we have to admit that memorisation and understanding figure as more basic and foundational domains for applying, analysing and eventually creating more knowledge. In other words, it means that without the mastering of some knowledge, no student could be able to use it or make it relevant for their lives.

It means that the creative aspect that comes out as the most evident result of any successful mastery of a particular language - being able to actually speak the language as well as proficiently write it - can not be reached without the corresponding process of getting to know the way such language works, which implies memorising some grammar and vocabulary information. One can not actually use a language without having learnt its most basic structures and vocabulary. It could not be more than an anecdote to think of someone who considered themselves to be a proficient user of any language as long as they held a very good translating applicative in their mobile. It would not work in real life, no matter how resourceful people they could be. They would not be considered a real user of this language.

However, one could say that Latin is not taught anymore to be spoken or used primarily as a means of communication, and, for that reason, there is no need of having prompt vocabulary or grammar to read a text. That is true only if one is comfortable reading an authentic text, even a very short one, which would still take a long time as to go over a dictionary or a grammar book in order to understand the morphosyntax and semantics of their structure before actually understanding it. Such a reading style would be rather discouraging and frustrating for most students. Moreover, real reading is a communicative action, it requires 
being able not only to decipher the mechanism of a language, but to understand, correlate, make inferences and eventually discuss what is being proposed by such text. Reading is in itself an engaged process, which results of being able to actively use a language and convey meaning (CARRELL et al. 1998).

Besides that, we would point out that many studies on Latin teaching have shown the advantages of facing Latin not as a dead or sacred language to be deciphered in reverence of a glorious past, and for that reason, a language so special and inaccessible that its use nowadays would mean something of a blasphemy. These studies contribute to advancing the idea that Latin, even though a classical language, is a language as any other, still capable of producing meaning nowadays, a language that has never ceased to live and communicate (LIMA, 1995; GRUBER-MILLER, 2006; FORTES 2010; MINKOVA \& TURNBERG, 2012; ENGELSING, 2014; PRATA \& FORTES, 2015). It means that in many ways Latin is much closer to a modern living language than we would suppose some decades ago. One example for this is the fact that Latin is very much alive as a vehicle for written communication through the internet ${ }^{2}$ or even for oral conversation in Latin Seminars ${ }^{3}$, all of which testify to an active and communicative use which has never truly ceased historically. As far as teaching goes, recently more and more teachers of Latin are prone to abandon the old structural methods prevailing after the mid 20th century to resume some traditional active strategies in their classrooms, such as written composition, translating into Latin and even carrying out small conversations as part of their language training (FORTES 2013; MEYNET, 2013, LEITE, 2015).

The idea behind these not so new techniques for teaching Latin is that Latin can be taught as a language as any other, the most important difference having to do with the fact that whilst modern language teaching would prioritise the development of oral communicative skills over reading skills, for a classical language such as Latin, the teaching would have the opposite priority, which means that orality must be seen as a means for reading. An important advantage of teaching Latin as a living language is that it may help students grasp and memorise vocabulary, grammar and pronunciation patterns of Latin much less painfully than it would be otherwise through the silent endless reading of grammar books or the mechanical repetition exercises ad nauseam. By actively using Latin in the classroom, through extempore communicative written or oral tasks, students may feel they are actually learning Latin, and not only solving linguistic problems through the use of the exceptional technological tools nowadays luckily available to students (or in some cases through the use of the old good dictionary and grammar books).

Out of the six goals proposed by Fink (2003) for the significant learning - knowledge, application, integration, human dimensions, caring and how-to-learn - an active approach to learning Latin must probably help go beyond the knowledge and application goals, enabling students to achieve integrational, how-to-learn and even caring and human dimensional goals, since they are required to assume a much more collectively engaged attitude in the classroom and go over all their previous knowledge on the subject to perform the tasks proposed.

\footnotetext{
${ }^{2}$ Actually, besides the interest of learning Latin for reading the classics and, by doing so, communicating with ancient civilisations, a scholarly interest that has never ceased to exist, we would also say that the emergence of the Internet and of global forms of communication has renewed the life of Latin as language of productive use. Today, a student of Latin can access international news in Latin, such as through the Finnish Broadcast Nuntii Latini (https://areena.yle.fi/1-1931339); change messages in Latin in social media or even use it for looking for information in the Wikipedia, which has a very comprehensive version in Latin. The same way there are initiatives in some countries where students and teachers of Latin get together to enhance their oral skills in this language.

${ }^{3}$ An example of this are the Conversational Latin Seminars hold by Professors Terence Turnberg and Milena Minkova in the University of Kentucky and in Dickinson College. These are summer workshops which have become internationally known for providing an occasion in which participants can live for an extended period of time in an all-Latin environment, speaking and hearing no language but Latin.
} 


\section{Teaching Latin grammar through active strategies: some examples}

We have a full undergraduate course on Classics at the Universidade Federal de Juiz de Fora, where students learn both the Latin and Greek languages, as well as their Literatures and Cultures. A particular objective of this undergraduate course is to provide students with the tools for them to become teachers of these languages. For that reason, not only do the students fulfill theoretical requirements on Classical Languages and Literatures, but they also have to take some courses on Teaching Methodology and Teaching Practice. In 2018 I was in charge of one of these Teaching Practice courses, in which I proposed the students the reflection and practice of active strategies for teaching Latin. Besides assigning some theoretical reading on this issue ${ }^{4}$, most of the classroom time was spent on modelling and performing active Latin tasks, so that the students' interest and feedback on these activities could be assessed and recorded. In each session a single activity consisting in actively using Latin was proposed. The focus was to show how controlled active use of Latin in the classroom could help students consolidate their previous grammar and vocabulary knowledge as well as be a way for their own learning self-evaluation and awareness.

The lessons were held mostly in Latin. Students were encouraged to speak Latin as much as they could, even if they made a lot of mistakes or took much time before producing an utterance. The class consisted of nearly 10 students, most of whom were advanced students of Latin. However, they had little or no experience in using Latin actively. For that reason, each lesson was divided in two parts: in the first section, a quick review of a specific grammar topic was conducted in Latin by the teacher, and in the second and longer part an active exercise was proposed, modelled and performed by students. For the introductory grammar explanations, class notes in Latin were handed in, based on Minkova's Introduction to Latin Prose Composition (2009), but simplified and translated into Latin. The idea of dividing the class in these two parts was that students could have some preliminary input in Latin, as well as could recall the grammar required for the active task to be developed in the sequence. No grammar topic presented was completely new to these students, but when they tried to use it actively, they had to ensure that they had learnt it sufficiently. The feedback received showed that most of the students believed they knew the grammar before the exercise, but they only realised they had not entirely assimilated it after trying to apply it in the exercise.

The grammar topics covered were mainly on the syntax of Latin, and covered the following components:

- Affirmative, negative, interrogative sentences in Latin

- Expression of deliberation, prohibition, wish, order, possibility, doubt

- Addition, disjunction, cause/consequence sentences

- Indirect questions

- Completive sentences with ut, quin, quod and verba timendi

- Relative sentences

- Temporal, causal, conditional, comparative sentences

The grammar contents were not properly introductory, since we had a class of high intermediate and advanced students. The choice on syntactic issues was due to my teaching experience which revealed that whereas students much more easily overcome Latin Morphology, they have much more difficulty in understanding syntax, which also happens to be crucial for extensive fluent reading of Latin.

\footnotetext{
${ }^{4}$ The theoretical bibliography on active practices in teaching Latin was Minkova \& Turnberg (2012); Leite (2015), Mertzani (2013).
} 
For each grammar topic, a different task was proposed, so that they could apply the theoretical knowledge to an active exercise, which forced them to show specific communicative abilities, as follows:

- Presenting themselves and presenting a character or someone else;

- Expressing wishes, plans and conditions;

- Describing pictures or videos and reacting to them;

- Making a dialogue and dramatising it;

- Provinding a summary for a text originally written in Latin;

- Writing a description or a narration in Latin;

- Explaining a poem orally;

- Paraphrasing a poem;

- Translating into Latin.

Every active task required the grammar topic previously shown in the classroom, as well as made students research for further vocabulary. The oral activities were prepared, rehearsed and presented in the classroom, while written activities were in general assigned as homework.

In the first lesson, for instance, the syntax of simple sentences in Latin was reviewed (see Appendix A). After this brief presentation, students were told to perform two different oral exercises (Appendix B). The first one was the replication of an exercise commonly used for teaching modern languages, consisting of asking students to work in pairs in order to present themselves in Latin and find out information about their partners. This first exercise intended to be a warm-up activity for the second task, which consisted of giving students pictures of famous Roman personalities (Caesar, Mark Antony, Cleopatra, Cicero, etc.) and asking them to research information about each of them and present them to the other students in class.

By doing these activities, the students had to put in practice what they had just seen in the previous grammar review: how to make simple sentences in Latin for making a question, affirming and negating. For the presentation, each group had some preparation time, when they could go over their own language knowledge necessary for performing this activity. Also, by researching Roman historical personalities, they also had to discuss about Roman culture, so that the language teaching was not completely apart from its original cultural background. Another example of an oral exercise consisted of giving students a set of Latin proverbs (see Appendix C). They had to read those proverbs, try to understand them in groups (they could talk in Portuguese for that activity) and, then, each one would have to engage in a conversation, in Latin. In this conversation, each student would take one of the proverbs to explain to the partner, so that they would have to use the indirect question structure, as well as completive sentences (as in the model presented, see Appendix D). An example of this dialogue was given to the students, so that they could use it as a hint for developing their own dialogues.

At the beginning, the students did not consider themselves capable of performing the exercises proposed. However, at the end of the lessons, not only did all the students manage to perform the task, but they also showed interest and engagement. The level of ease and familiarity with the exercises varied according to the student's different learning styles, as well as according to their level of instruction in Latin. However, in general, speaking Latin seemed to be in itself a very exciting idea, so that the students seemed to perform the tasks joyfully. And the confidence of speaking in Latin, even in a very controlled way, significantly increased as the course went on. The key to making students feel more confortable and less critical of their own performance was not to take this time as a serious academic assignment to grade them, but as playful activities for them to have fun with their peers and teacher.

As we see, they were not complex activities that required much effort to be carried out in the classroom. They did not require an extensive planning nor many resources. Even so, 
someone might still doubt whether these active tasks are really necessary for teaching grammar, when the old traditional grammar exercises might produce the same effect with less teaching effort. After all, what is the point of taking classroom time for listening to students speak Latin?

\section{Why to teach Latin through active strategies}

In their book, Teach Students How to Learn (2015), Saundra McGuire and Stephanie McGuire tell the story of hundreds of American students who had bad results in basic disciplines, such as Physics, Calculus or Chemistry, but who overcame their difficulties by simply becoming more aware of their own learning process. McGuire \& McGuire show that the reason for the students' ultimate success was the acquisition of a more responsible learning attitude. For this reason, McGuire \& McGuire advocate for every teacher to help students become more aware of their own responsibility for learning.

The authors highlight the importance of teaching students metacognitive resources, which can be helpful for the learning process, one of which is the very understanding of the difference between learning and studying. In fact, whilst studying a subject could be defined as the mechanical and repetitive act of going over a textbook in order to answer the questions for a test (the what-based instruction model), learning would require students to go beyond answering "what is something?", to be able to answer "how and why is that so?" and "what-if it happened to be different?" (MCGUIRE \& MCGUIRE, 2015, p. 31). It means that effective learning is much more than efficient studying for passing a test, it requires from the learners a much more active attitude towards the objective of learning.

The use of active strategies in class for helping students learn Latin can be a remarkably interesting way of making students go beyond studying Latin to actually enable them to learn this language. In fact, when a teacher model Latin oral production in the classroom in order to give them tasks to reproduce it in groups or individually, not only must the students be able to recall what they may have learnt so far, but also to understand the other dimensions of knowledge, i.e. how, why does the language work this way? and principally: what-if we could speak it today? What if we could communicate in Latin? How would it be done? Why should I use this or that other way of making a sentence? These or those words?

Someone might claim that these students, by doing so, are not really speaking or writing in Latin, since their linguistic output would hardly be recognised by a native Roman as authentic Latin. As we can no longer come across native speakers of Latin, in order to ask them if our extempore classroom Latin would actually meet the standards of native-like chat, and because the remaining authentic texts in Latin have come to posterity mostly through written, often literary forms, there is little doubt about the fact that every extempore use of Latin - for teaching purposes or not - can not be taken as really authentic Classical Latin ${ }^{5}$.

However, the question if a student output represents or not strictly authentic samples of Classical Latin is of little relevance for their learning process. If we take for instance the teaching of a Modern Language, the question would make much less sense. Let's take the teaching of English as a Foreign Language. The fact that in an EFL classroom a beginner student produces a text that would be hardly recognised as Shakespearean English does not diminish the fact that he/she is really learning it. Even if this student makes mistakes that would perhaps be unacceptable to the most sensitive ears, no one would tell he/she is not actually learning this language. The point is that making mistakes, the old trial and error method, is inherently connected to learning, including learning a language, in which competence can never

\footnotetext{
5 The debate if this extempore use of Latin is Classical Latin or not seems to be an interesting issue for contemporary Latinists. We may not ignore the fact that some Latin is actually being used actively for many purposes nowadays besides the reading of the classical authors. That seems to be a very interesting phenomenon on which we can not simply turn our backs.
} 
be achieved unless we try (ZULL, 2011, p. 54; BROWN, 2007, p. 227). It means that the fact that a student's Latin oral performance is full of mistakes when compared to authentic Ciceronian Latin does not imply necessarily that the use of this poor classroom Latin is not of any use for their learning process.

One more reason for using active strategies in Latin teaching: the advantage of getting students working collaboratively. The teaching of Latin restricted to the reading of texts in classroom, making translations, studying grammar and doing structural exercises does not in general engage students in pair or group activities. It means that after some classes, the classroom time gets very repetitive and students may lose their interest in the subject as they have to follow monotone regular reading or grammar lessons, as we learn from teaching experience. By adding some active tasks once in a while, as a complementary part of a lesson, the teacher has an opportunity to provide students with more a relaxing and joyful moments, that may help them change their mindset, since it also might change their cognitive style and also their learning habit. In fact the idea that interaction plays an important role for learning a language is not new (ALLWRIGHT, 1984, p. 233-234). In the same way, by proposing these exercises, a teacher can think of different class groupings, which might enhance the establishment of a more comfortable classroom environment, as many studies on this matter also show (GREGORY \& PARRY, 2006; HOPPER, 2013; BRANSFORD et al., 2000).

\section{Some conclusive remarks}

The idea of incorporating active strategies into the teaching of Latin is not new. On the contrary: what is quite recent is teaching Latin without using it actively. Indeed, since ancient times up to the $19^{\text {th }}$ century, one could not imagine a Latin class without the idea of listening, speaking, reading and writing in Latin (MINKOVA \& TURNBERG, 2012). The reasons why the use of writing and speaking declined in Latin pedagogy can be accounted for historically, however the negative effects of that change are the idea that Latin is not a common language, or it is a language too difficult to be learnt since nobody can actually speak anything in it.

By resuming activities of teaching Latin grammar through active tasks engaging students in oral activities or making them write in Latin, we do not intend to teach to speak Latin per se, it only means that such strategies might help students acquire more confidence in the use of grammar and vocabulary as well as make classroom time more interesting and favourable to effective learning. Incorporating active tasks for teaching Latin has the potential of boosting the language acquisition, since it can more easily cover other goals not explicitly dealt with in traditional grammar classes, by promoting integration and learning awareness, resulting therefore in a more significant learning.

\section{$5 \quad$ References}

ANDERSON, L. W. et al. A taxonomy of learning teaching and assessing: a revision in Bloom's taxonomy of educational objectives. New York, NY: Longman, 2001.

ALLWRIGHT, R. L. The importance of interaction in classroom language learning. Applied Linguistics, Volume 5, Issue 2, Summer 1984. 156-171, https://doi.org/10.1093/applin/5.2.156

BRANSFORD, J. D. et al. (ed.) How people learn: brain, mind experience and school. Washington, DC: National Academy Press, 2000. 
BROWN, H. D. Principles of language learning and teaching. 5. ed. White Plaims, NY: Pearson, 2007.

CARRELL, P. L. et al. (ed.) Interactive approaches to second language reading. New York, NY: Cambridge, 1998.

ENGELSING, E. M. Latim, biquíni e sinfonia discordante: línguas clássicas e metodologia de ensino. Organon, Porto Alegre, v. 29, n. 56, jan/jun. 2014. 99-121.

Fink, L. D. Creating significant learning experiences: an integrated approach to designing college courses. San Francisco: Jossey-Bass, 2003.

FORTES, F. S. A 'língua'e os textos: gramática e tradição no ensino de latim. Instrumento: Revista de Ensino e Pesquisa em Educação. Juiz de Fora, vol. 12, n. 1, p. 63-70, 2010.

FORTES, F. S. O ensino de latim centrado no uso da língua e na aquisição de competências. PhaoS - Revista de Estudos Clássicos. Campinas: UNICAMP, v. 13, p. 7-21, 2013.

GREGORY, G. \& PARRY, T. Designing brain-compatible learning. Thousand Oaks, CA: Corwin Press, 2006.

GRUBER-MILLER, J. When dead tongues speak. teaching Beginning Greek and Latin. Oxford: Oxford University, 2006.

HOPPER, C. H. Practicing college learning strategies. 6. ed. Boston, MA: Wadsworth, 2013.

LEITE, L. R. Aprendendo a ler - e a falar - em latim. In: Prata, P. \& Fortes, F. O Latim hoje: reflexões sobre cultura clássica e ensino. São Paulo: Mercado de Letras, 2015.

LIMA, A. D. Uma estranha língua? Questões de linguagem e de método. São Paulo: UNESP, 1995.

MCGUIRE, S. Y \& MCGUIRE, S. Teach students how to learn. Strategies you can incorporate into any course to improve student metacognition, study skills, and motivation. Sterling, VA: Stylus, 2015.

MEYNET, B. C. Problemas detectados en relación con la enseñanza tradicional del latín. PhaoS - 2013 (13), 65-92. Disponível em:

http://revistas.iel.unicamp.br/index.php/phaos/article/view/4611/5085, acesso em 20.mai.2020.

MINKOVA, M. \& TURNBERG, T. Active Latin: speaking, writing, hearing the language. New England Classical Journal, vol. 39, n.2, 2012. 113-128.

MINKOVA, M. Introduction to Latin prose composition. Mundellein, Ill.: BolchazyCarducci, 2009.

MERTZANI, M. Communicative language teaching in Ancient Greek Primary Classes. PhaoS - 2013 (13), pp. 119-136. Disponível em: 
http://revistas.iel.unicamp.br/index.php/phaos/article/view/4611/5085, acesso em 20.mai.2020.

PRATA, P. (Org.) ; FORTES, F. (Org.) O latim hoje: reflexões sobre cultura clássica e ensino. 1. ed. Campinas: Mercado de Letras, 2015.

ZULL, J. E. From brain to mind: using neuroscience to guide change in education. Sterling, VA: Stylus, 2011. 
Appendix A: Lesson 1 - Grammar Review in Classroom - in Latin (based in Minkova, 2009)

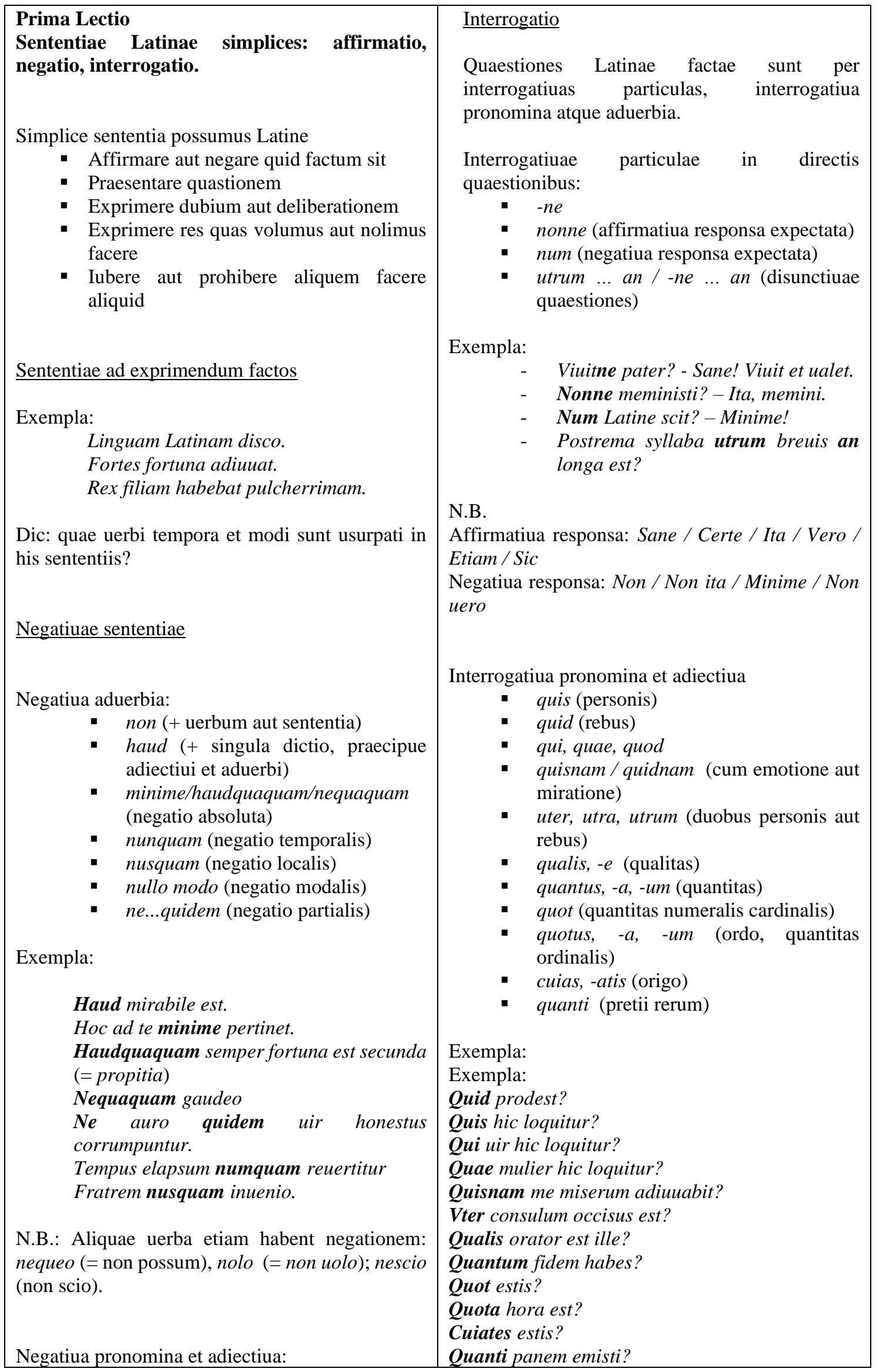




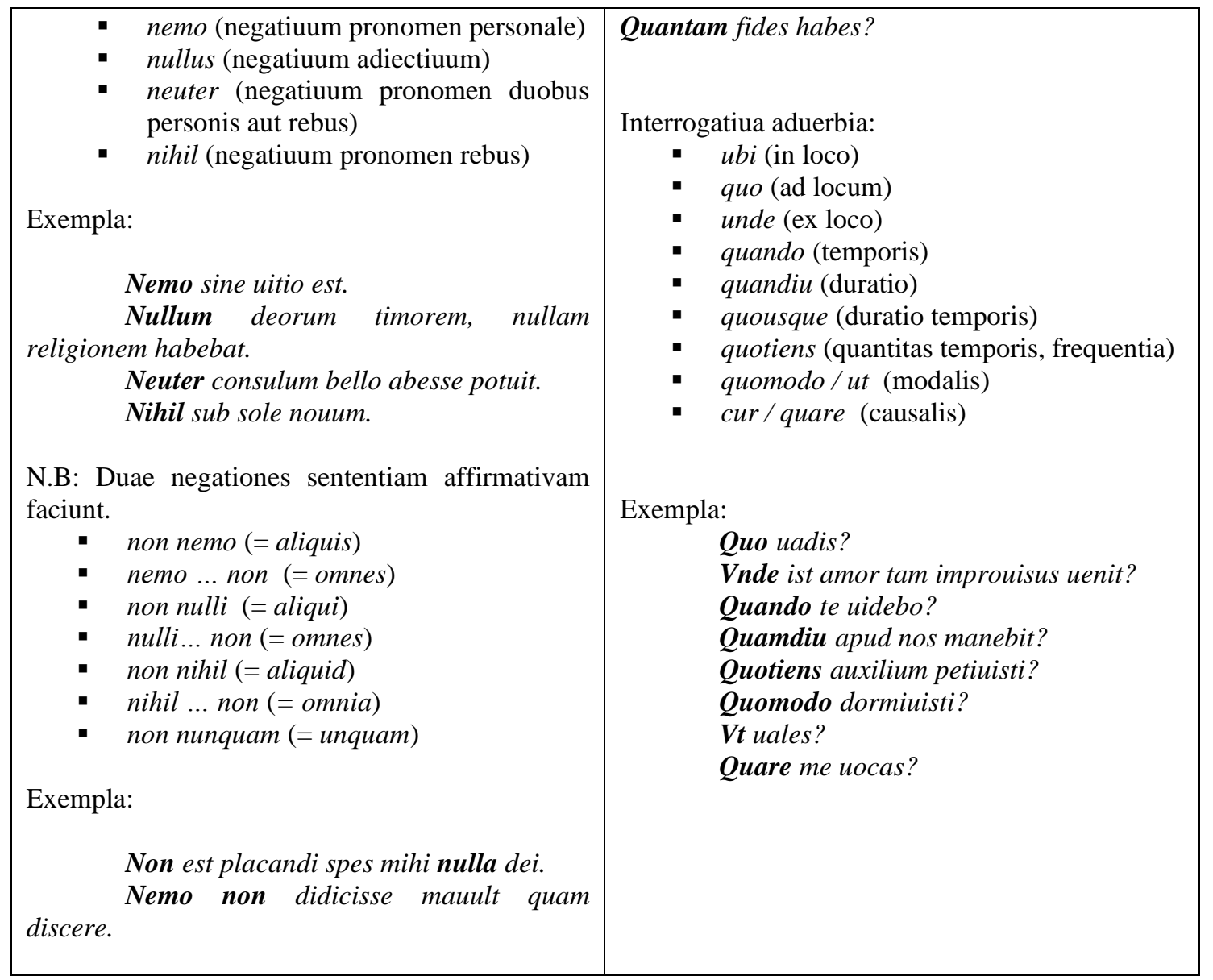


Appendix B: Lesson 1 - Oral Practice (Simple sentences in Latin)

\title{
Exercitationes
}

I. In paribus, praesentate sibi. Offerite collegae uestri informationes personales uestras, ut quid studeas, quae res uobis placeant, ubi habites, quandiu in hoc schola studeas etc.

II. In paribus, parate breuem praesentationem de personalitatibus romanis (Vide imaginem ad uobis datam a magistro).

In uostra praesentatione, debetis respondere:

Quis est?

Vbi nascitur, uiuit et moritur?

Quando uiuit?

Quandiu uiuit?

Quid facit et per quem est clarus?

Quid putas de eo?

etc.

\section{Appendix C: Latin Proverbs}

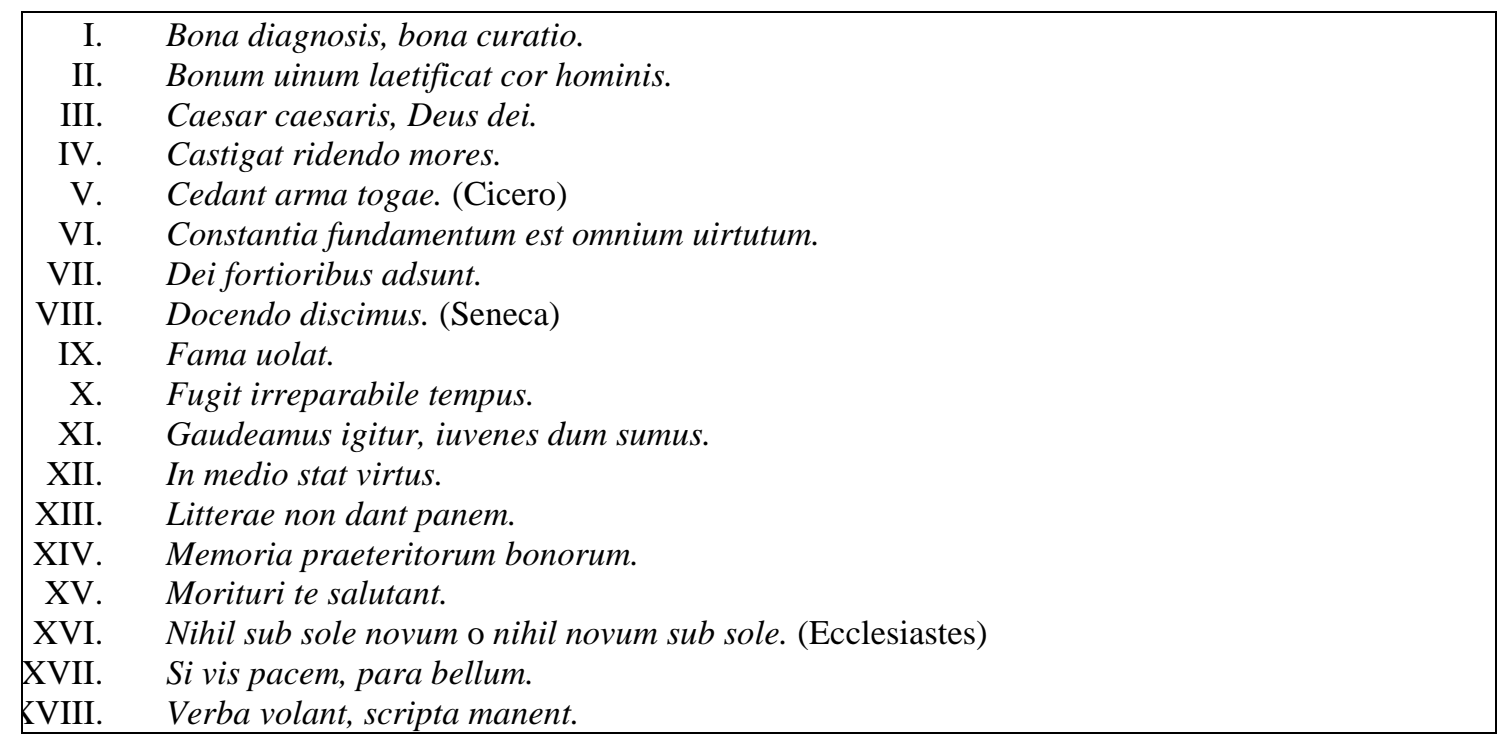

Appendix D : Lesson 4 - Oral Practice (Indirect questions)

\author{
$\underline{\text { Exercitationes }}$ \\ Legete haec prouerbia latina, postea uerbis suis ea explicate. Postea, dicite num consentite aut non et quare. \\ Vtimini quaestiones indirectas atque orationes infinitiuas. \\ Facite sicut in exemplo: \\ Prouerbium: "Ars longa, uita breuis" \\ A: Volo scire quid hoc prouerbium significat. \\ B: Per hoc prouerbium, Romani credebant dum artem longam esse, uitam tamen breuem esse. \\ A: Consentisne cum hoc prouerbio? \\ B: Maxime! Vita nostra uero fugit celeriter.
}

